\title{
Islamic Values of The Northern Town Square of the Yogyakarta Sultanate
}

\author{
Suparwoko ${ }^{1}$, Wiryono Raharjo $^{1}$, and Ahmad Saifudin ${ }^{1}$
}

Received: 28 January 2020

Accepted: 23 May 2020

\begin{abstract}
Since the end of the 13th century during the era of the Majapahit Kingdom, the Public Square or town square has always become part of the kingdom. The square is a manifestation of public space, an integral part of the spatial layout of the royal capital. This concept was later adopted by cities in Indonesia, which provides an open space right in front of the palace or government office. Public squares as public spaces can play various roles in enhancing the quality of urban life, especially to express the social economic and environmental values. This paper aims to solely focus on the northern town square located inside the palace complex, especially by addressing the Islamic values of the northern town square of the Yogyakarta Sultanate using qualitative approaches in terms of its social economic and environmental aspects. Primary data were directly obtained from the research location by taking some photographs, field observation, and notes, while secondary data were derived from the literature and the Internet. The research suggests that the northern town square serves as the symbol and manifestation of not only the media to relate mankind to God but also the media to relate mankind to nature. In terms of mankind-to-God relation, the northern town square serves as a place for Eid prayers every year, including the Eid Fitr and the Eid Adha. Also, some annual events like the Sekaten are held every year to commemorate the birth of the Prophet Muhammad. The Sekaten Fun Fair to celebrate the birth of the Prophet highlights the Islamic values related to social economic and tourism activities. In the context of northern town square landscape, the element of 64-banyan trees around the northern town square symbolizes the age of the Prophet Muhammad. This tree concept has been successfully protected the environment around the northern town square and serves as a public open space in the city of Yogyakarta.
\end{abstract}

Keywords: Islamic value, town square, Eid pray, Sekaten, Yogyakarta

\section{INTRODUCTION}

Original The northern town square is an important part of the heritage sites of Yogyakarta Palace. In the last three years (2016-2018), there has been a significantly increased level of tourist visits to Yogyakarta. From the data from the Yogyakarta City Tourism Office, the number of tourists visiting Yogyakarta in 2016 was 3,547,352. In 2017 the number of tourist visits rose to 3,894,771, and in 2018 it soared to 4,103,240 people (Dinas Pariwisata Kota Yogyakarta, 2018). A research report published by the Pew Research Centre, in the middle of March 2017 states that Islam is a religion with the fastest-growing number of adherents in the world. The Muslim population in Indonesia as a country with the largest Muslim population in the world amounted to 203 million or $88 \%$ of the total worldwide Muslim population. Likewise, a large number of the Muslim population lives in the city of Yogyakarta (Pew Research Center, 2017). Out of the 422, 732 number of population of Yogyakarta in 2017, 83\% or 350868 people of which are Muslim (Badan Pusat Statistik Kota Yogyakarta, 2018). Based on the trend of tourist visits

\footnotetext{
${ }^{1}$ Department of Architecture, Islamic University of Indonesia, Yogyakarta, Indonesia
} 
in Yogyakarta and the worldwide number of Muslims as well as the Muslims in the city of Yogyakarta, the Islamic value of the northern town square as a tourist attraction becomes a crucial aspect to support the value of tourism assets of the city of Yogyakarta as a whole northern town square. In the 7th century AD following the collapse of the Roman Empire, Islam became a newly emerging power. Its appearance was marked by the amazing development of a new Islamic civilization as indicated by the thriving Islamic culture, science, and technology as well as other social lives including the economy (Akmal \& Abidin, 2015). Islam is the primordial religion of man - the racket al-fitrah. Islam, derived from an Arabic word, means submission, surrender, and obedience (Crescent Peace Society, n.d.). As a religion, Islam represents total obedience and submission to Allah. The uncovered word of God, the Qur'an, is the epitome of Truth and sets the reason for an Islamic lifestyle. The Qur'an gives fundamental rules and standards to human exchanges and a hypothetical system for the parameters of Muslim development. The Sunnah or the way of life of the Prophet Muhammad SAW is viewed as the representation of Islam in real life. The Sunnah comprises of what the Prophet had stated, what he did, and what he endorsed of or permitted. Together, the Qur'an and the Sunnah are the Absolute Reference Frame (ARF) of the Muslim human advancement (Sardar, 1988). In this regard, the values of the Islamic religion are the concept of high appreciation by the community towards several principal issues in life-based on the Quran and hadiths or sunnah of the prophet. Some important activities annually use the northern town square of Yogyakarta are the Eid pray and the Sekaten traditional ceremony.

Therefore, the question relevant to the northern town square of Yogyakarta is that how does the square support the Islamic values based on the space use and environmental aspects. This study aims to analyse the Islamic values of the Northern town square of the Yogyakarta Sultanate. The analysis is to focus on 1) the role of the square for the annual Eid pray; 2) the contribution of the square for the traditional Sekaten ceremony, and 3) the function of the square as a part of urban open space and landscape.

\section{Previous Studies relating the Northern town square of Yogyakarta}

Run by Widarnaryani et. al. in 2003, a morphological study and change in functions of the north square of the Yogyakarta palace addresses the decline of space quality, environment, and sense of place includes the decrease of the cultural value and commercial tendency as parts of the northern town square problems (Widarnaryani \& Ikaputra, 2003). In this study, the cultural value was discussed excluding the Islamic value. By a different highlight, a study in 2008 of the imaginary axis as a basic morphology in the city of Yogyakarta, Indonesia is valuable due to the role of religions as a cosmological orientation to connect various cosmic forces (Karsono \& Wahid, 2008). A research in 2012 discusses the northern town square as a memorable square which focuses on identities, meanings and the production of urban space in Yogyakarta (Widiyastuti, 2012). However, there is no highlight for the Islamic value of this study due to more discussion on the absence of institution and management together with the lack of planning regulation have reduced the importance of the square.

The study in 2016, Yeru examines the direct impacts on its inhabitants and this approach works in the Southern Town Square, Yogyakarta with introducing the traditional game called masangin that is practiced every day in The Southern Square. This research suggested that a traditional game provided in the southern town square had a positive impact on economic and tourism activities in Yogyakarta. In 2017 the study of city heritage of the Mataram Islamic Kingdom in Indonesia with a case study of Yogyakarta palace (Wardani, Soedarsono, Haryono, \& Suryo, 2013) focuses historical and aesthetic values concerning on the four main components called catur gatra tunggal. The northern town square was included in the concept of the catur gatra tunggal together with the palace, the 
mosque, and the market. This study resulted in some valuable components of architectural quality and a social life that are well developed and sustained. However, the Islamic value of the square was not discussed. Another research in 2018 has examined the dynamic the square based on the change of form, function, and meaning aspects (Ashadi, 2017). This research inspires the crucial aspect of meaning as a cultural symbol of the physical structure that is relevant to this current study of the Islamic value of the northern town square.

Most previous studies above are concerning to the northern town square did not discuss the Islamic values. Therefore, this current study focusing on the Islamic values of the northern town square in Yogyakarta is valuable and crucial due to the exploration of the role of the square based on the social-economic and landscape environment.

\section{Islamic Value and Public Open Space}

Islamic values are the level of personal integrity that reaches the level of conscience (human beings). Islamic values are the absolute truth that is universal and holy. The truth and goodness of religion overcome ratios, feelings, desires, human desires and can transcend the subjectivity of groups, races, nations, and social stratification (R. B. Putra, 2012). That concept is supported by Al-Quran containing general principles in Islam for various problems of Islamic law, especially those related to things that are muamalah (social) (Nasution, 1986). The Social angle in man is associated with Islam, Allah's Religion which He, the Most Gracious, decided for His slaves and by which He completes His Divine Messages through Quran (Nabulsi, 2012). Humans who believe in the attributes of Allah will believe that their existence as Allah's servants is so small that humans need to be humble and encourage their obedience to worship and do good deeds (Yahya, 2018).

Travlou and Thompson say that open space is an essential part of the urban heritage, a strong element in a city's architectural and aesthetic form, plays an important educational role, is ecologically important, is important to social interaction and to foster community development, and supports economic goals and activities. It helps in specific to decrease the tension and conflict in deprived parts of Europe's metropolitan regions; it plays a significant part in meeting a community's recreational and recreational requirements and has an economic value in improving the environment (Travlou \& Thompson, 2007). It is inversed that urban space is crucial to be seen for social-economic activities and environmental aspects.

Due to the Eid pray and the Sekaten cultural ceremony, Salzbrunn has studied how migrants who have grown up in secular nations use American public space by organizing unique activities to show their political and religious identity. Although migrants, particularly political and religious activists, take into account the cultural and political differences between their various locations of residence, they pursue ongoing approaches across their trans-local areas (SALZBRUNN, 2004). In this respect, social-economic activities concerning the use of the northern town square of Yogyakarta are the Eid pray and the Sekaten traditional ceremony. The environment aspect of the square that will be explored is the role of the square as a part of an urban landscape. The landscape is a composition of elements including buildings, paving, landform, water, and planting (gardenvisit.com, 2019b).

\section{The Eid Pray and the square use}

It is urgent to explore some aspects concerning Islamic worship and deeds such as cultural ceremonies that are provided on the northern town square, as an urban open space in Yogyakarta. As Islamic worship and deeds, the Eid pray annually is vital to be held on the field or square. It is addressed by Mahbib in 2019 that the best place for conducting Eid prayer according to the sunnah is the field unless there are obstacles such as rain or other obstacles (Mahbib, 2019; Baits, 2018). What Mahbib mentioned was based on the hadith of 
Abu Sa'id al-Khudri: The Prophet Muhammad came out to the field when Eid al-Fitr and Eid al-Adha. The first prayer that he did for the first time was the Eid prayer. (Narrated by Bukhari and Muslim): Ibnul Haj al-Makki said: the sunnah that has been in effect for long before Eid prayers are carried out in the field. This is because the prophet Muhammad said: "Prayers in my mosque (the Nabawi mosque) are more important than a thousand times of prayer in addition to my mosque, except the haram." Despite having a very big virtue, the Prophet SAW remained out towards the field and leave the mosque. (al-Madkhal, 2: 438).

The procedure when heading to the field is including: 1) Depart and return to take a different path, that the Prophet SAW when the feast took a different path (Narrated by Bukhari), 2) It is recommended that the public come to the field early. As for the Imam, it is recommended to arrive rather late until the prayer time begins, 3) bertakbir (recite soundly Allah $\mathrm{Hu}$ Akbar) since from home until arriving at the field, 4) Cannot carry weapons, unless forced Al-Hasan al-Basri said: they are prohibited from carrying weapons on holidays, unless they are afraid of an enemy (Narrated by Bukhari).

Walking to depart and return to take a different path is good for the soul and save humanity. The reason is that walking can play in making people and cities healthier (Pucher \& Buehler, 2010). The Eid prayers (jamaah) declare soundly the name of Allah in the field before and after the Eid prayers. The is based on the Quran that we pronounce takbir, tahmid, and tasbih as a form of gratitude for the guidance of Allah as he said: "... And you should suffice the numbers and you should glorify God for His instructions given to you, so that you give thanks," (Qs Al -Baqarah: 185).

\section{The Sekaten of the Square use}

As a public space, the northern town square is very valuable to Muslim in Yogyakarta and surrounding. Because the square is not only for socio-economic and environmental interests but also cultural interests. The Sekaten ceremony becomes a tradition that is still preserved by the people of Yogyakarta because it has strong historical roots. That approach is relevant to the existence of the north town square of Yogyakarta that is annually used to provide the Sekaten cultural ceremony due to social, cultural, and economic activities inside the event. The ritual series of Sekaten ceremonies started from Miyos Gangsa, Tumplak Wajik, Kondur Gangsa, Garebeg, and Bedhol Songsong (Karaton Ngayogyakarta Hadiningrat., 2018). Sekaten is a tradition to commemorate the birthday of the Prophet Muhammad (Heryanto, 2010). Equally important is the strengthening of the social function of urban space as a meeting place that contributes to social sustainability goals (Gehl, 2011a).

The Sekaten ceremony is annually delivered in the northern town square and this event draws domestic and overseas visitors. In this respect, a great open space can significantly affect the economical existence of big or small urban centers. As towns progressively contend with each other to pull in investment, the nearness of respectable parks, squares, gardens, and other open spaces turn into a fundamental business and promote instrument: corporations or businesses are pulled into areas that offer wellplanned, well-overseen open spots and these draw in visitors, employees, and services (Carr, Francis, Rivlin, \& Stone, 1992). Moreover, urban Open Space brings together opportunities and benefits from various types of open spaces for people and individuals. Urban open spaces can provide social, economic, health, and environmental benefits and opportunities for the community that they might use for an everyday basis. Some best practices of urban open space utilization can be categorized in new developments and community initiatives (Woolley, 2003). 


\section{The Environmental Aspect and Urban Landscape}

As a universal religion, Islam regulates all aspects of human life, including how ethical it is towards nature and the environment. Nature and the environment are an integral part of human life because all human needs originate and are fulfilled by the surrounding environment from both plants and animals. Therefore, Islam advised through the Quran that humans must preserve the surrounding environment to avoid their survival from the actions of a group of people who do not want to preserve nature. On this basis, the teachings of Islam provide signs for humans to be ethical towards the environment (Harahap, 2015).

In the perspective of Islam, humans and the environment have a very close relationship because Allah created this universe including humans and the environment in balance and harmony to be maintained so as not to suffer damage (R. A. M. Putra, 2016). Because of the human domination over nature, especially the existence of environmental damage,Allah has reminded us by the Surah Al - A'raf verse 56: "And do not do damage on the earth, after God has repaired it and prayed to Him with fear (not will be accepted) and hope (will be granted). Surely the mercy of Allah is very close to those who do good deeds." In this respect, open spaces and squares are the crucial elements in urban area and cities. Landscape integrates some elements of buildings or structure, paving, landform, water, and planting [18]. Therefore, in terms of the environment, the variable of the landscape will be delivered to the data and discussion. As a part of an urban landscape, public squares also constitute as social facilities, as on the article 1 letter d Minister of Home Affairs Regulation No. 1 of 1987 states that "Social Facilities are facilities needed by communities in residential or urban areas which includes, among others: 1. Education; 2. Health; 3. Shopping and commerce; 4. Government and public services; 5. worship; 6. Recreation and culture; 7. Sports and open fields. 8. Public Cemetery" (Loulanski \& Loulanski, 2011).

\section{METHOD}

This research location focused on the northern town square of Yogyakarta and its related surrounding area of the square including the Gedhe Mosque, the Palace/Keraton, the Paku Alaman, and the Kepatihan. The research conducted mainly qualitative approaches in terms of its social economic and environmental aspects with supports of graphical and quantitative data. Primary data were directly taken from the location by making some photographs, field observation, and notes. The crucial secondary data were obtained from the printed literature and the Internet. The main components to be analyzed in this study were the Eid prayer as religious events and the Sekaten as a cultural due to their usages of the northern town square as public urban space in Yogyakarta. The qualitative measurements (Fletcher, 2015) based on the normative Islamic concept (Quran and Hadith) and precedents based on the cultural Islamic history in Java (Yahya, 2018) (Azra, 2004), Indonesia were conducted. Another component to be analyzed was the environment of the square and the analyses addressed mainly qualitative with support of quantitative and graphical figures. The environmental indicator used in this method concerned with landscape variables including landform, vegetation, paving, and building (gardenvisit.com, 2019a; Meijering, Tobi, van den Brink, Morris, \& Bruns, 2015).

This segment creates matrixes relating components of analysis and elements of Islamic values. The first analysis matrix of the Eid pray event includes: 1) the elements analysis of sequence process from to the field of pray, and 2) the component of analysis focusing Islamic concept, spatial usage, and Islamic value. The second analysis matrix of the Sekaten ceremony contains 1) the element of analysis for the ritual sequence of the Sekaten, and the component of analysis based on the order of the spatial usage, the elements Islamic concept or precedent, and the Islamic value. The third analysis matrix of 
the environmental landscape covers 1) the element of the landscape which are a landform, planting, paving, and building structures, and 2) the component analysis such as the form of landscape, function or activities, and the Islamic value based on the beneficial aspects. After the matrix analysis had been conducted, the in-dept analysis was to be addressed by using qualitative and triangulation analysis to develop and highlight the discussion and findings.

\section{The Northern Town Square and Public Open Space in Yogyakarta}

Javanese society is one of the largest ethnic groups in Southeast Asia, and about eighty-five percent of its people embrace Islam (Mulder, 2007). The arrival of Islam in Java as well as in Sumatra is believed to take place in the first century of Hijri (Islamic Calendar) or around the 7th century AD. The spread of Islam in Java was warmly welcomed by the Javanese because Muslims tended to spread their teachings without eliminating Javanese customs and culture at that time (Suyono, 2012). Yogyakarta besides being popular as an education city is also known as a city of culture and tourism, which is quite famous not only in Indonesia but also in the international world. The rapid development of Yogyakarta was managed by the Xth Sri Sultan Hamengku Buwono, who was also the head of regional government. He maintained the integrity of the ancestral culture, which was preserved for generations. One culture that is still preserved from the beginning of the establishment of the government in Yogyakarta until now is the continuing implementation of a traditional ritual called Sekaten.

Sekaten is a tradition to commemorate the birthday of the Prophet Muhammad. Historically, this tradition was one of the Islamic traditions that had been carried out at the beginning of the reign of the Demak Islamic kingdom. This tradition is developed from the previous tradition carried out by Javanese people who believe in Hinduism and Buddhism. Previously, during the kingdom of Majapahit (1293-1500 M), the people carried out a celestial tradition, accompanied by mantras, which were intended as offerings to the gods, as well as to honor the spirits of the ancestors. However, when the Majapahit Kingdom collapsed, and Raden Patah (the first king of Demak Kingdom) established the Demak Islamic kingdom (1500-1550 AD), accompanied by the support of the trustees, the Sekaten celebration was subsequently transformed into Islamic-based activities to seek blessings and guidance from Allah SWT and the recitation of the spells were changed to reciting verses from the Quran and Hadith (Heryanto, 2010). The northern town square stretches for $300 \mathrm{x}$ 300 square meters. In the middle of it, stood two brackets of Banyan Trees, planted on the west and the east of the square axis. According to Salokapatra document, the seed of the west Banyan Tree was from the Majapahit Kingdom and the seed of the east Banyan Tree was obtained from the Pajajaran Kingdom. Between the two trees, there is a line of philosophical axis of Yogyakarta. The entire surface of the northern town square is covered with soft sand. 62 Banyan trees are surrounding the northern town square. Along with two Banyan Trees in the middle of the square, and there are 64 Banyan Trees (Kratonjogja.id, 2018).

\section{The Northern Town Square and the Islamic Value Analysis}

\section{The Islamic Value of the Square due to the Eid Pray}

When the Eid Al-Fitr or the Eid al-Adha arrives, all non-aging Muslims are encouraged to leave their houses, including the women who are on period. Everyone at that time is encouraged to show happiness and joy. Eid Al Fitr prayer is sunnah muakkadah (highly recommended). Since it was recited in the second year of the Hijrah, the Prophet never left the prayer until he died, which was continued by his companions (Mahbib, 2019). 
The northern town square Square of Yogyakarta in every year could play a role as an open area or outdoor mosque for Eid praying (see Table 1). This confirms with the Eid Pray that was done by the Prophet Muhammad on the field as a place to pray as a sunnah (Mahbib, 2019)(Baits, 2018). In this respect, the square can be a meeting public space to unique activities such as Eid pray to show the religious identity (SALZBRUNN, 2004) in Yogyakarta. The Eid prayers are recommended to walk in going to the field for praying and this concept crucial because walking is good for 1) soul and save humanity (Elledge, 2018), and 2) making social interaction (Gehl, 2011a).

Table 2. The Eid Prayer in the Yogyakarta Northern Town Square

\begin{tabular}{|c|c|c|c|c|}
\hline No & Eid Prayer's Act & Islamic Concept & Spatial Usage & Islamic Value \\
\hline 1 & $\begin{array}{l}\text { Eid Prayer out from } \\
\text { home }\end{array}$ & $\begin{array}{l}\text { The Prophet } \\
\text { (Muhammad) came out } \\
\text { to the field when Eid al- } \\
\text { Fitri and Eid al-Adha } \\
\text { (Narrated by Bukhari } \\
\text { and Muslim) }\end{array}$ & $\begin{array}{l}\text { On the west part } \\
\text { of the northern } \\
\text { town square }\end{array}$ & $\begin{array}{l}\text { The Prophet said," The } \\
\text { whole earth is a mosque } \\
\text { except graves and } \\
\text { bathrooms / lavatories." } \\
\text { (Abu Sa'id Al Khudri). As } \\
\text { public space, the square is a } \\
\text { meeting place (Gehl, } \\
\text { 2011a) for praying. }\end{array}$ \\
\hline 2 & $\begin{array}{l}\text { Walking to the } \\
\text { square/ field while } \\
\text { walking with calm } \\
\text { and submission. }\end{array}$ & $\begin{array}{l}\text { The Prophet went out to } \\
\text { the field on foot and he } \\
\text { went home too by } \\
\text { walking. (HR. Ibn Majah } \\
\text { and disavowed al-Albani) }\end{array}$ & $\begin{array}{l}\text { Pedestrian path } \\
\text { from the jamaah } \\
\text { houses to the } \\
\text { Square }\end{array}$ & $\begin{array}{l}\text { Urban walking is good for } \\
\text { the soul and save humanity } \\
\text { (Elledge, 2018). By } \\
\text { walking, the prayer in the } \\
\text { square is supporting soul } \\
\text { and humanity. }\end{array}$ \\
\hline 3 & $\begin{array}{l}\text { Going to the } \\
\text { field/square and } \\
\text { returning from the } \\
\text { mosque, the jamaah } \\
\text { walk by taking a } \\
\text { different path. }\end{array}$ & $\begin{array}{l}\text { From Jabir bin Abdillah } \\
\text { radhiyallahu 'anhuma, } \\
\text { that the Prophet on the } \\
\text { feast of Eid took a } \\
\text { different path (between } \\
\text { when he departed and } \\
\text { when he returned) (HR } \\
\text { Bukhari). }\end{array}$ & $\begin{array}{l}\text { Pedestrian path to } \\
\text { the northern town } \\
\text { square }\end{array}$ & $\begin{array}{l}\text { Public space, pedestrianism } \\
\text { and the role of city space } \\
\text { serve as a meeting place for } \\
\text { urban dwellers (Gehl, } \\
\text { 2011b). On pedestrians, } \\
\text { people have opportunity to } \\
\text { greet each other and make } \\
\text { social interaction (Gehl, } \\
\text { 2011a). }\end{array}$ \\
\hline 4 & $\begin{array}{l}\text { It is } \\
\text { recommended for } \\
\text { the Eid prayer to } \\
\text { arrive in the field } \\
\text { early. }\end{array}$ & $\begin{array}{l}\text { The priest is } \\
\text { recommended to arrive } \\
\text { late until the prayer time } \\
\text { begins. Because the priest } \\
\text { is waiting instead of } \\
\text { waiting. }\end{array}$ & $\begin{array}{l}\text { On the west part } \\
\text { of the northern } \\
\text { town square }\end{array}$ & $\begin{array}{l}\text { Discipline in using time } \\
\text { means respecting time well, } \\
\text { because one of the keys to } \\
\text { succeed is the ability to use } \\
\text { time well (Rahma, 2019). }\end{array}$ \\
\hline 5 & $\begin{array}{l}\text { People utter takbir } \\
\text { from home until } \\
\text { they arrive in the } \\
\text { field or the } \\
\text { square. }\end{array}$ & $\begin{array}{l}\text { The authentic history } \\
\text { of Ibn Umar, that he } \\
\text { hardened the takbir } \\
\text { reading (for men) } \\
\text { during Eid al-Fitr and } \\
\text { Eid al-Adha when } \\
\text { heading to the } \\
\text { field/square, until the } \\
\text { priest arrived }\end{array}$ & $\begin{array}{l}\text { Along the way to } \\
\text { the field and on } \\
\text { the field }\end{array}$ & $\begin{array}{l}\text { Along the way and on the } \\
\text { square as public space, } \\
\text { Muslims glorify God's } \\
\text { name } \\
\text { (Khazanahalquran.com, } \\
\text { 2017). }\end{array}$ \\
\hline 6 & $\begin{array}{l}\text { All worshipers } \\
\text { may not carry } \\
\text { weapons }\end{array}$ & $\begin{array}{l}\text { Al-Hasan al-Basri said: } \\
\text { They are prohibited } \\
\text { from carrying weapons } \\
\text { on holidays, unless } \\
\text { they are afraid of an } \\
\text { enemy. (Narrated by } \\
\text { Bukhari) }\end{array}$ & $\begin{array}{l}\text { Along the way to } \\
\text { the field and on } \\
\text { the field }\end{array}$ & $\begin{array}{l}\text { Prohibition of carrying } \\
\text { sharp weapons in the city } \\
\text { area to avoid criminal acts } \\
\text { or improve security } \\
\text { (Redaksi, 2019). }\end{array}$ \\
\hline
\end{tabular}

The procedure when heading to the field is including: 1) Depart and return to take a different path, that the Prophet SAW when the feast took a different path (Narrated by Bukhari), 2) It is recommended that the public come to the field early. As for the Imam, it is recommended to arrive rather late until the prayer time begins, 3) bertakbir (pronounce 
Allah hu Akbar) since from home until arriving at the field, 4) Cannot carry weapons, unless forced Al-Hasan al-Basri said: they are prohibited from carrying weapons on holidays, unless they are afraid of an enemy (Narrated by Bukhari) [20]. Walking to depart and return to take a different path is good for the soul and save humanity. The reason is that walking can play in making people and cities healthier (Pucher \& Buehler, 2010). By walking on more pedestrians, more people have several opportunities to make social interaction or human contact (Gehl, 2011a) (Gehl, 2011b). During the way to the field and in the field, the Eid prayers (jamaah) declare soundly the name of Allah in the field before and after the Eid prayers. The is based on the Quran that we pronounce takbir, tahmid, and tasbih as a form of gratitude for the guidance of Allah as he said: "... And you should suffice the numbers and you should glorify God for His instructions given to you, so that you give thanks," (Qs Al -Baqarah: 185).

As social activities, the worship of the Eid prayer is conducted at the northern town square in the front of the Great Mosque by the government of Yogyakarta. This value is also supported by the concept of the catur gatra tunggal in which the Square together with the great mosque brings the symbol of the relationship between the people and God (Kratonjogja.id, 2018; Wardani et al., 2013; Wibowo, 2012). This also informs that in the urban area, pedestrian and open spaces such as the northern town square is an integrated infrastructure for people (Office of Economic Resilience Development Office of Community Planning and Development United States Department of Housing and Development, n.d.; Qian, Zhu, Zhou, \& Chen, 2018; Tanuwidjaja \& Chang, 2017). The jamaah are encouraged to come early to the northern town square since they have to use their time well [40] as a part of better management and respect to other people (Askari, Soltani, \& Ahmad, 2015; McNaughton, Morrison, \& Schill, 2016). It is recommended that along the way towards the field as on public spaces, Muslims shall glorify God's name (Islamic Relief Worldwide, 2015; Joseph Rowntree Foundation, n.d.; Khazanahalquran.com, 2017) and to motivate the religious spirit in celebrating the Eid ceremony (Bykov, 2012; Muralidharan \& La Ferle, 2018). All worshipers must prioritize people's safety in public areas such as open spaces, and thus they may not carry any weapons (Redaksi, 2019).

\section{The Islamic Value of the Square due to the Sekaten Ceremony}

Sekaten is held for a week starting from the 5th to 11th Rabiul Awal. The 12th Rabiul Awal is the peak of the Sekaten celebration or known as Grebeg Maulud. The Sekaten Fun Fair is held for a month, starting a month before the Grebeg event begins (Sudirman, 2014). The series of Sekaten ceremonies started from Miyos Gangsa, Tumplak Wajik, Kondur Gangsa, Garebeg, and Bedhol Songsong (Karaton Ngayogyakarta Hadiningrat., 2018; Karaton Ngyogyakarta Hadiningrat, 2019) (See Table 3). Traditional ceremonies in social institutions are full of symbols that function as communication devices between fellow citizens [54]. The birthday is usually celebrated with a festive party or just a simple celebration. The anniversary moment is considered as a beginning to move towards the future with better hopes (Arifan, 2012). A birthday is a sign of expression of joy, hope, and respect, including by following the example of the person in charge, such as the celebration of the Birthday of the Prophet Muhammad. The celebration of the Maulud was conducted traditionally since the kingdom of Demak. Raden Patah, the King of Demak named it Sekaten, to commemorate the birthday and to broadcast Islam for the people through the spirit of harmony and peace.

The Sekaten or Sekati ritual was based on the transformation of the Hindu culture (during the Majapahit Kingdom) to the Islamic culture (during the Mataram Kingdom). This transformation process is included in the bid' ah. Bid'ah or heresy is a method or model of activity in a religion created or innovated to resemble sharia-based worship. It aims to take or do something as a form of worship based on sharia teaching. Therefore, in 
Islam, heresy refers to innovation in religious matters. Based on the precedent, the bid' ah took place after the collapse of the Majapahit Kingdom and the establishment of the Demak Islamic Kingdom by Raden Patah (the first King of the Demak Kingdom) accompanied by the support of the trustees. Raden Patah transformed the Hindu celebration into a celebration with an Islamic value to seek blessings and virtues from Allah SWT. He also changed the recitations of the mantra to reciting verses from the Quran (Heryanto, 2010). The transformation process began during the Islamic Mataram Kingdom in Demak by Sunan Kalijaga as he used local culture to process Islamization in Java (Yahya, 2018; Azra, 2004).

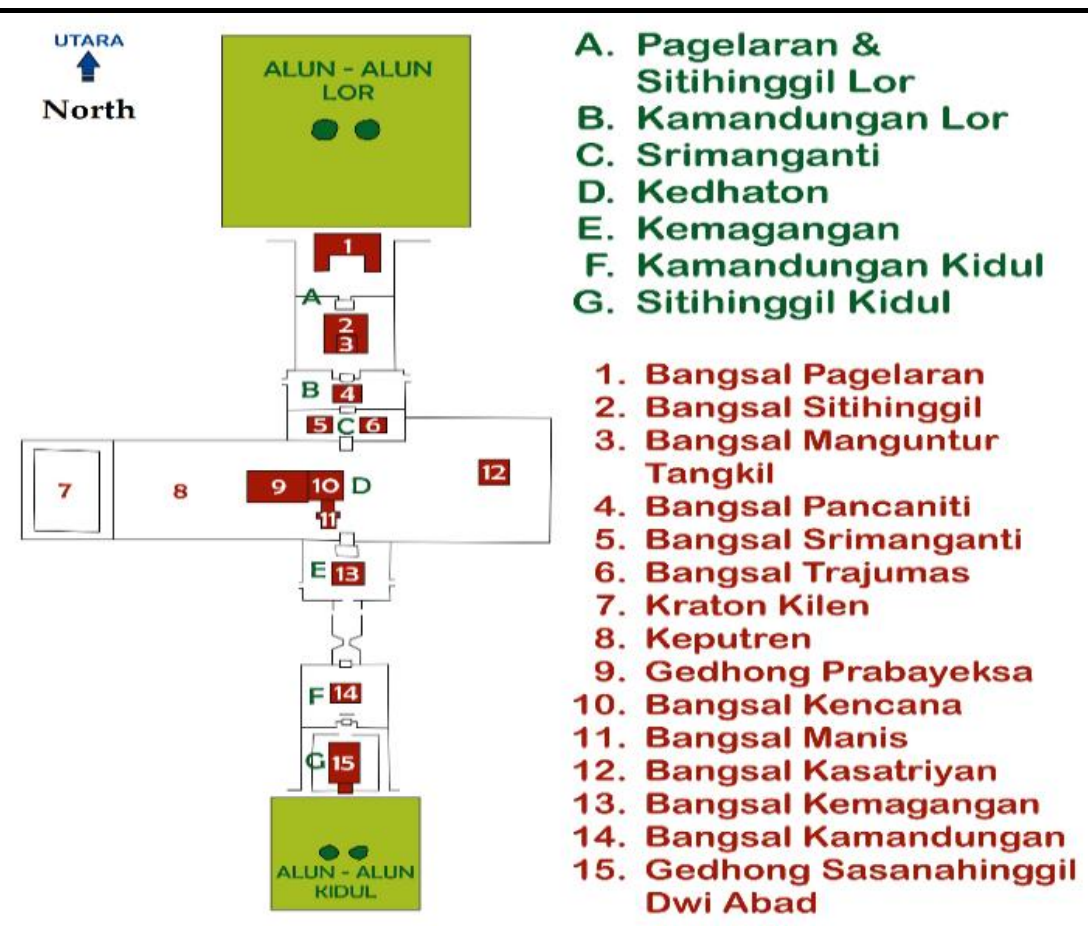

Source: Redraw from (Kratonjogja.id, 2017)

Figure 1 Keraton Yogyakarta Plan

The ritual ceremony of the Miyos Gangsa, Tumplak Wajik, Kondur Gangsa, Garebeg, except the Bedhol Songsong must use the space of the northern town square. This means that the Sekaten tradition is supporting Islamic preaching (Karaton Ngayogyakarta Hadiningrat., 2018). According to the Yogyakarta (Islamic Mataram Empire), sekati means shahadatain [8]. Syahadatain means two sentences of creed, which are two sentences of testimony indicating that a person is a Muslim.

The Sekaten ceremony is realized by using symbols of the human soul to continue to draw closer to God. In the material form, the symbol is shared with the community as a courtesy and charity (Mirawati, 2016). The Sekaten is also an identity [9] of the northern town square of Yogyakarta as the Sekaten Fun Fair is conducted annually due to the commemorate of birth of the Prophet Muhammad by accommodating several activities, including art performance, funfair, attraction rides, various entertainment and games, and culinary tourism. "In addition to being a method of promotion, trade, and tourism by involving the community and entrepreneurs, the Sekaten can be interpreted to have the essential value," said Deputy Governor of the Special Region of Jogjakarta in the northern town square of Yogyakarta on Friday $(2 / 11 / 2018)$ afternoon. This concept confirms to 
Widiastuti and Diyah concerning the meaning of a birthday according to Islam (Diyah, 2013; Widiyastuti, 2012) that also results in the enhancement of visitors, employees, and services (Woolley \& Rose, 2003) in Yogyakarta. Various events were held in the Sekaten Fun Fair. Starting from activities about culture and religion, and the Fun Fair event which is always held in the northern town square of the Yogyakarta Palace. Thousands of merchants spilled out in the courtyard of the palace of the Sultan Hamengku Buwono. In this Sekaten Fun Fair event, various food vendors, clothing, accessories, to entertainment can be found easily. This highlights that the northern town square can serve as a recreational area because both passive and active recreation can take place on the square (Harahap, 2015) to support local social economy interaction and community development.



Source: Redraw from (Behrend, 1982)

Figure 2. Path of the Royal Procession in the Garebeg Maulud Ceremony.

Table 3. Sekaten and the Spatial Usage

\begin{tabular}{|c|c|c|c|c|}
\hline & $\begin{array}{l}\text { Sekaten } \\
\text { Ritual }\end{array}$ & $\begin{array}{l}\text { Spatial Usage } \\
\text { (See Figure 1, } \\
\text { and Figure 2) }\end{array}$ & $\begin{array}{l}\text { Islamic } \\
\text { Concept or } \\
\text { Precedent }\end{array}$ & $\begin{array}{l}\text { Islamic Value of } \\
\text { the northern } \\
\text { town square }\end{array}$ \\
\hline 1 & $\begin{array}{l}\text { "Miyos } \\
\text { Gongso" (the } \\
\text { release of the } \\
\text { gamelan to } \\
\text { the Gedhe } \\
\text { Mosque) }\end{array}$ & $\begin{array}{l}\text { Front of the } \\
\text { mosque to } \\
\text { invite people. } \\
\text { Road: Keraton } \\
\text { - Square - the } \\
\text { Mosque } \\
\text { (Karaton } \\
\text { Ngayogyakarta } \\
\text { Hadiningrat., } \\
\text { 2018) }\end{array}$ & $\begin{array}{l}\text { Sunan } \\
\text { Kalijaga knew } \\
\text { that the } \\
\text { Javanese } \\
\text { people } \\
\text { enjoyed the } \\
\text { celebration } \\
\text { accompanied } \\
\text { by the } \\
\text { presence of }\end{array}$ & $\begin{array}{l}\text { The northern } \\
\text { town square } \\
\text { serves as a } \\
\text { meeting place to } \\
\text { of Muslim in } \\
\text { Yogyakarta to } \\
\text { the Prophet } \\
\text { Muhammad } \\
\text { SAW. }\end{array}$ \\
\hline 2 & $\begin{array}{l}\text { Tumplak } \\
\text { Wajik: } \\
\text { a. Start } \\
\text { making the } \\
\text { Gunungan } \\
\text { b. Rehearsal } \\
\text { of the Sultan } \\
\text { Soldier }\end{array}$ & $\begin{array}{l}\text { Panti Pareden } \\
\text { in the Palace } \\
\text { The northern } \\
\text { town square } \\
\text { (Karaton } \\
\text { Ngayogyakarta } \\
\text { Hadiningrat., } \\
\text { 2018) }\end{array}$ & $\begin{array}{l}\text { gamelan, to } \\
\text { invite the } \\
\text { public to } \\
\text { welcome the } \\
\text { birthday } \\
\text { celebration of } \\
\text { the Prophet } \\
\text { Muhammad. }\end{array}$ & $\begin{array}{l}\text { Jalaluddin As- } \\
\text { Suyuthi (749- } \\
911 \mathrm{H} \text { ) says that } \\
\text { commemorating } \\
\text { the birthday of } \\
\text { the Prophet } \\
\text { Muhammad is } \\
\text { permissible } \\
\text { because it is a }\end{array}$ \\
\hline
\end{tabular}




\begin{tabular}{|c|c|c|c|c|}
\hline & $\begin{array}{l}\text { Sekaten } \\
\text { Ritual }\end{array}$ & $\begin{array}{l}\text { Spatial Usage } \\
\text { (See Figure 1, } \\
\text { and Figure 2) }\end{array}$ & $\begin{array}{l}\text { Islamic } \\
\text { Concept or } \\
\text { Precedent }\end{array}$ & $\begin{array}{l}\text { Islamic Value of } \\
\text { the northern } \\
\text { town square }\end{array}$ \\
\hline 3 & $\begin{array}{l}\text { Kondur } \\
\text { Gongso } \\
\text { Reading of } \\
\text { the Prophet's } \\
\text { History } \\
\text { The } \\
\text { procession of } \\
\text { the gamelan } \\
\text { is back to the } \\
\text { Sultan Palace }\end{array}$ & $\begin{array}{l}\text { The Great } \\
\text { Mosque } \\
\text { The Great } \\
\text { Mosque - the } \\
\text { northern town } \\
\text { square - the } \\
\text { Palace } \\
\text { (Karaton } \\
\text { Ngayogyakarta } \\
\text { Hadiningrat., } \\
\text { 2018) }\end{array}$ & \multirow{3}{*}{$\begin{array}{l}\text { Gamelan } \\
\text { music } \\
\text { attracted the } \\
\text { attention of } \\
\text { the public to } \\
\text { come to the } \\
\text { square and } \\
\text { approach the } \\
\text { mosque to } \\
\text { follow the } \\
\text { preaching } \\
\text { Islam. } \\
\text { There is no } \\
\text { command or } \\
\text { suggestion in } \\
\text { Islamic } \\
\text { provision to } \\
\text { commemorate } \\
\text { the birthday } \\
\text { of Prophet } \\
\text { Muhammad } \\
\text { SAW and it is } \\
\text { categorized as } \\
\text { bid'ah } \\
\text { (heresy). }\end{array}$} & \multirow[t]{3}{*}{$\begin{array}{l}\text { manifestation of } \\
\text { the love and } \\
\text { honour of } \\
\text { Muslims to His } \\
\text { Messenger. }\end{array}$} \\
\hline 4 & $\begin{array}{l}\text { Gerebeg } \\
\text { Maulud } \\
\text { The } \\
\text { Gunungans } \\
\text { are } \\
\text { distributed to } \\
\text { three } \\
\text { different } \\
\text { places }\end{array}$ & $\begin{array}{l}\text { The Palace - } \\
\text { The northern } \\
\text { town square - } \\
\text { the Gedhe } \\
\text { Mosque, Paku } \\
\text { Alaman, } \\
\text { Kepatihan } \\
\text { (Karaton } \\
\text { Ngayogyakarta } \\
\text { Hadiningrat., } \\
\text { 2018) }\end{array}$ & & \\
\hline 5 & $\begin{array}{l}\text { Bedol } \\
\text { Songsong: } \\
\text { The Sekati } \\
\text { gamelan is } \\
\text { returned to } \\
\text { the palace }\end{array}$ & $\begin{array}{l}\text { Pagelaran } \\
\text { Sitihinggil in } \\
\text { the Kraton } \\
\text { area }\end{array}$ & & \\
\hline 6 & $\begin{array}{l}\text { Sekaten Fun } \\
\text { Fair } \\
\text { Celebration } \\
\text { for } 30-40 \\
\text { days or one } \\
\text { month by: } \\
\text { a. a art } \\
\text { performance } \\
\text { b. night } \\
\text { market } \\
\text { c. Attraction } \\
\text { rides } \\
\text { d. Various } \\
\text { entertainment } \\
\text { and games } \\
\text { e. culinary } \\
\text { tourism }\end{array}$ & $\begin{array}{l}\text { The northern } \\
\text { town square } \\
\text { (Karaton } \\
\text { Ngayogyakarta } \\
\text { Hadiningrat., } \\
\text { 2018) }\end{array}$ & $\begin{array}{l}\text { Al-Haff Ibn } \\
\text { Katsir } \\
\text { Rahimahullah } \\
\text { explained that } \\
\text { with these } \\
\text { verses, Allah } \\
\text { SWT } \\
\text { educated His } \\
\text { faithful } \\
\text { servants } \\
\text { related to } \\
\text { mu'amalah } \\
\text { (social order } \\
\text { and behavior) } \\
\text { towards } \\
\text { Rasulullah, } \\
\text { which must } \\
\text { glorify and } \\
\text { respect. }\end{array}$ & $\begin{array}{l}\text { The Square as a } \\
\text { meeting place } \\
\text { for recreational, } \\
\text { social, cultural, } \\
\text { economic } \\
\text { activities. the } \\
\text { Sekaten Night } \\
\text { Market is a } \\
\text { means of } \\
\text { cultural } \\
\text { preservation, } \\
\text { community } \\
\text { entertainment } \\
\text { and as a means } \\
\text { of supporting } \\
\text { the economy by } \\
\text { holding } \\
\text { Sekaten a } \\
\text { celebration for } \\
\text { one month }\end{array}$ \\
\hline
\end{tabular}

\section{The Islamic Values of the Northern Town Square due to the Environment.}

Overall, the area of the Northern town square of Yogyakarta covers about $300 \times 300$ $\mathrm{m} 2(90,000 \mathrm{~m} 2)$. The landscape element of the Northern town square includes land, paving, planting, and building or structure with no water element. The element of land is about $70 \%$ of the total area $(63,000 \mathrm{~m} 2)$. This land is for water infiltration and social and economic activities, especially the Sekaten Ceremony. With a maximum run-off coefficient of 0.10 , the Northern town square can absorb $90 \%$ of the main waterfall on the square. This 
is good for the Northern town square to conserve the rainwater. The Sekaten celebration is held each year in the Northern town square and that event uses all open space (land) of the northern town square. The other crucial activity on the Northern town square is the Eid Prayer that is also held annually. There is no permanent building on the northern town square used to accommodate the Sekaten and the Eid prayer. Those events (of the Sekaten and the Eid prayer) take place due to a cultural and religious concept.

This value of the Eid prayer and the Sekaten demand the existence of the northern town square as an open space without permanent structure. This suggests that the Eid prayer and the Sekaten can preserve the northern town square as an urban open space that is a part of the urban environment in Yogyakarta (Harahap, 2015). This also confirms the hadith that the Quran and the Prophet Muhammad have reminded people to conserve the environment to avoid disaster. The Islamic value is that the Eid Prayer supports and preserves the existence of urban open spaces such as the northern town square of Yogyakarta. Based on the Quran and Hadith: the religion that the Prophet Muhammad brought, namely Islam, became a blessing for the universe. This also means that everything or all actions that can benefit nature, including humans, animals, and plants, are of the Islamic value (Yahya, 2018).

As social facilities, the northern town square can facilitate people concerning on field education, trading during the Sekaten, public services, worship, recreation and culture, and outdoor sports. These various activities confirm to the article 1 letter $d$ Minister of Home Affairs Regulation No. 1 of 1987 (R. A. M. Putra, 2016), The permanent and nonpermanent buildings surrounding the Northern town square are used for institutional and tourism (social and economic) activities. The institutional buildings include offices, auditorium, gallery, and museum. Non-permanent buildings or structures mostly are for tourism activities such as street vendors, cafés, and restaurants. Paving on the northern town square includes paving blocks and asphalt surfaces. Most paving is used for pedestrian and vehicles. Therefore, this access element of landscape in the northern town square can support tourism and transportation as social facilities (R. A. M. Putra, 2016) on the square and its surrounding area. Vegetation or planting in the northern town square of Yogyakarta is mainly dominated by banyan trees with a total number of 64 trees. The number of 64 is the symbol of the age of the Prophet Muhammad based on the Islamic or Javanese calendars (Kratonjogja.id, 2018). The advantages of the banyan trees are 1) as oxygen producers, 2) as shade trees, 2) the ability to absorb water in the soil, 3) as absorbers of $\mathrm{CO} 2$ pollution, 4) the ability to adapt to various environmental conditions, and 5) hundreds of years of age (DPUPKP Kabupaten Bantul, 2018).

Table 4. Environment: Landscape Elements of the Northern Town Square $300 \times 300$ m2

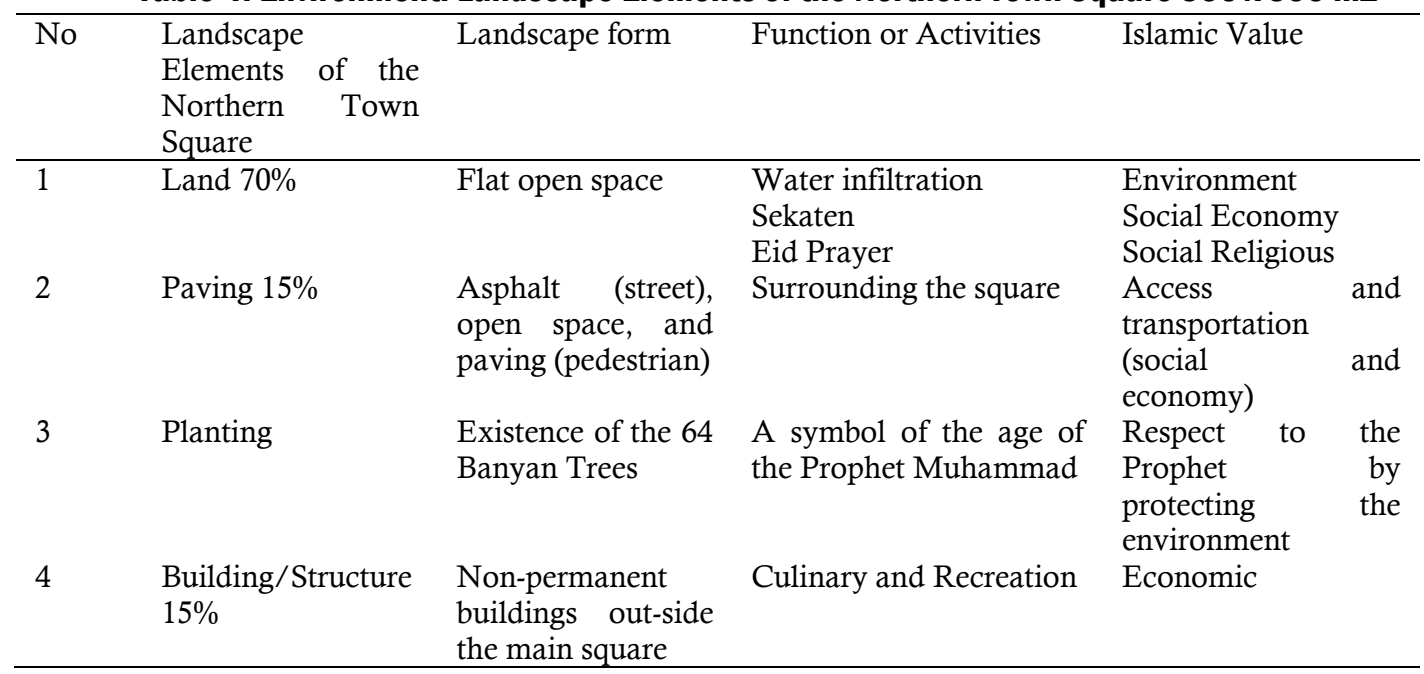


Building or structure elements on the northern town square is about $10 \%$ or $9,600 \mathrm{~m} 2$ that is predominantly used for restaurant, street vendor, food stalls, auditorium, and some offices (including a museum and art gallery). Those activities (informal and formal) on the area of the northern town square support and represent the square for tourism including recreational and culinary activities. This confirms that humans must preserve the urban environment by maintaining the existence of the northern town square in Yogyakarta urban area (Harahap, 2015). This also represents a typology for the northern town square as urban open space that serves as a regional park, square, recreation, playground, and sports field that can encourage social and economic activities in urban areas (Wallbank \& James, 2010). The northern town square typology could arrange an ecological system that would decrease the scene of discontinuity, and increment the multifaceted shape of nature of green space fixes and available scene. Subsequently, the nature of the urban ecological condition would be improved ( $\mathrm{Li}$, Chen, \& He, 2015). Unlike the Bandung town square that more than $50 \%$ of the area is covered by paving and building structure because there is no a specific value such as the Eid pray that covers almost $50 \%$ of the Yogyakarta northern town square and also the Sekaten Fun Fair that covers almost 100\% of the land of the Yogyakarta northern town square. Therefore, these two rituals can keep the large size of the square due to respect to the Islamic worship (of the Eid prey) and the birthday celebration of the Prophet Muhammad (as the Sekaten ceremony). The Islamic value that lies here is that people and the earth have a clear relationship since Allah made this universe including the people and nature in equalization and concordance that must be kept up so as not to cause any harm (Harahap, 2015).

\section{CONCLUSION}

The Islamic values of the northern town square of Yogyakarta can protect the existence of the square by accommodating the Eid pray (including Eid Fitr and Eid Adha) and the gerebeg maulud due to the Sekaten ceremony. Accommodating the Eid prayers on the northern town square of Yogyakarta is to follow the sunnah. The element of walking is crucial in the context of Eid ritual and healthy city concept. Therefore, the government needs to encourage more people to walk with regards to promote safe and convenient pedestrian infrastructure such as sidewalks, crosswalks, and intersection crossings to support people-friendly urban design. Walking can also improve traffic pollution and reduce using motorized vehicles. Moreover, the Sekaten ceremony is a religious and cultural symbol of the Yogyakarta Sultanate that has been the success to manage that annual event as living urban identity to encourage economic and tourism industry in Yogyakarta. The deep Islamic value of the existence of the 64-banyan tree aims to motivate people to protect and preserve trees around the town square by psychologically holding the Prophet's message. This banyan tree concept has been strongly conserved the environment around the northern town square and serves as a public open space in the city of Yogyakarta. However, the size of some town squares in Indonesia have been penetrated by paving and building structures. Therefore, to protect town squares in many regions, any government or community can implement the Islamic values by addressing the Eid pray and annual agenda of cultural tourism, and also planting 64-banyan trees around the town squares. Finally, this study will contribute that the religious and cultural messages are strongly potential to conserve and protect urban open spaces that is valuable for urban design process and development.

\section{ACKNOWLEDGEMENTS}

This paper is the result of the activities financed by the Ministry of Research and Technology of Higher Education through the National Strategy scheme in 2017-2019. The author says greatly love for Research and Technology Ministry of Higher Education that 
has funded the research of National Strategy for three years. Thanks also go to the DPPM UII and the FTSP UII who have supported the researcher with the awesome management.

\section{REFERENCES}

Akmal, \& Abidin, Z. (2015). Korelasi Antara Islam dan Ekonomi. Jurnal Penelitian, 9(1).

Arifan, F. A. (2012). Perayaan Ulang Tahun: Budaya Murni ataukah Bid'ah. Retrieved May 23, 2019, from Kompasiana.com https://www.kompasiana.com/fadh_ahmad/55110f67a333112f3cba8fe8/perayaan-ulang-tahunbudaya-murni-ataukah-bid-ah

Ashadi, A. (2017). The Change of Form , Function, and Meaning of The City Open Space ( Alun-Alun ) in Traditional Cities of Java, Indonesia. International Seminar and Workshop on Urban Planning and Community Development.

Askari, A. H., Soltani, S., \& Ahmad, I. M. (2015). Engagement in public open spaces across age groups: The case of Merdeka Square in Kuala Lumpur city, Malaysia. Urban Design International. https://doi.org/10.1057/udi.2014.5

Azra, A. (2004). Jaringan Ulama Timur Tengah dan Kepulauan Nusantara Abad XVII \& XVIII: Akar Pembaruan Islam Nusantara, edisi revisi. Jakarta: Kencana Prenada Media Group.

Badan Pusat Statistik Kota Yogyakarta. (2018). Yogyakarta dalam Angka 2018. Retrieved June 18, 2019, from Badan Pusat Statistik Kota Yogyakarta website: https://jogjakota.bps.go.id/publication/2018/08/16/8e60dd366fc77ddeee9ea008/kota-yogyakartadalam-angka-2018.html

Baits, U. A. N. (2018). Panduan Shalat Idul Adha dan Idul Fitri. Retrieved from konsultasisyariah.com website: https://konsultasisyariah.com/14531-panduan-idul-adha.html

Behrend, T. E. (1982). Kraton and Cosmos in Traditional Java. University of Wisconsin-Madison.

Bykov, A. K. (2012). The Formation of the Spirit of Patriotism in Young People. Russian Education \& Society. https://doi.org/10.2753/res1060-9393540205

Carr, S., Francis, M., Rivlin, L. G., \& Stone, A. M. (1992). value of public space. In Public Space.

Crescent Peace Society. (n.d.). Facts about Islam. Retrieved May 17, 2019, from crescentpeace.org website: http://nursing.kumc.edu/Documents/son/fsep/CPS-Islam-3.pdf

Dinas Pariwisata Kota Yogyakarta. (2018). Perkembangan Total Kunjungan Wisatawan Kota Yogyakarta 2018. Retrieved June 18, 2019, from pariwisata.jogjakota.go.id website: https://pariwisata.jogjakota.go.id/

Diyah. (2013). Makna Hari Ulang tahun Menurut Islam. Retrieved May 24, 2019, from wordpress.com website: https://iyah2008.wordpress.com/2013/08/20/makna-hari-ulang-tahun-menurut-islam/

DPUPKP Kabupaten Bantul. (2018). Pohon Perindang Jalan. Retrieved July 20, 2019, from dpupkp.bantulkab.go.id website: https://dpupkp.bantulkab.go.id/berita/142-pohon-perindang-jalan

Elledge, J. (2018). Urban walking isn't just good for the soul. It could save humanity. The Guardian.

Fletcher, E. (2015). Interpreting qualitative data. International Journal of Research \& Method in Education. https://doi.org/10.1080/1743727x.2015.1066173

gardenvisit.com. (2019a). Definitions of landscape, landscape design, landscape architecture, landscape planning and EID. Retrieved June 14, 2019, from gardenvisit.com website: https://www.gardenvisit.com/landscape_architecture/landscape_debate/definition_eid

gardenvisit.com. (2019b). The importance of landscape architecture. Retrieved from gardenvisit.com website: https://www.gardenvisit.com/landscape_architecture $\% 0 \mathrm{D}$

Gehl, J. (2011a). Cities for people. International Journal of Sustainability in Higher Education. https://doi.org/10.1108/ijshe.2011.24912daa.008

Gehl, J. (2011b). Life Between Buildings. In Science. https://doi.org/10.1126/science.1072994

Harahap, R. Z. (2015). ETIKA ISLAM DALAM MENGELOLA LINGKUNGAN HIDUP. Jurnal EduTech, 1(1). Retrieved from ETIKA ISLAM DALAM MENGELOLA LINGKUNGAN HIDUP

Heryanto, F. (2010). Mengenal Keraton Ngayogyakarta Hadiningrat. Yogyakarta: Warna Mediasindo.

Islamic Relief Worldwide. (2015). Islamic Declaration on Global Climate Change. International Islamic Climate Change Symposium.

Joseph Rowntree Foundation. (n.d.). The social value of public spaces. Retrieved from https://www.jrf.org.uk/sites/default/files/jrf/migrated/files/2050-public-space-community.pdf 
Karaton Ngayogyakarta Hadiningrat. (2018). Upacara Sekaten dan Garebeg Mulud Be 1952. Retrieved from kratonjogja.id website: https://www.kratonjogja.id/peristiwa/59/upacara-sekaten-dan-garebeg-muludbe- $1952 \% 0 \mathrm{D}$

Karaton Ngyogyakarta Hadiningrat. (2019). Hari Besar Islam. Retrieved June 11, 2019, from kratonjogja.id website: https://www.kratonjogja.id/hari-besar-islam

Karsono, B., \& Wahid, J. (2008). Imaginary Axis as a basic morphology in the city of yogyakarta Indonesia. INTERNATIONAL CONFERENCE ON BUILT ENVIRONMENT IN DEVELOPING COUNTRIES.

Khazanahalquran.com. (2017). Tahukah Anda Makna "Takbir” yang Sebenarnya?

Kratonjogja.id. (2017). Tata Ruang dan Bangunan Kawasan Inti Keraton Yogyakarta. Retrieved June 12, 2019, from Kratonjogja.id website: https://www.kratonjogja.id/tata-rakiting-wewangunan/4/tata-ruang-danbangunan-kawasan-inti-keraton-yogyakarta

Kratonjogja.id. (2018). Alun-Alun Yogyakarta. Retrieved June 18, 2019, from Kratonjogja.id website: https://www.kratonjogja.id/tata-rakiting-wewangunan/15/alun-alun-yogyakarta

Li, H., Chen, W., \& He, W. (2015). Planning of green space ecological network in urban areas: An example of Nanchang, China. International Journal of Environmental Research and Public Health. https://doi.org/10.3390/ijerph121012889

Loulanski, T., \& Loulanski, V. (2011). The sustainable integration of cultural heritage and tourism: a metastudy. Journal of Sustainable Tourism, 19(7), 837-862. https://doi.org/10.1080/09669582.2011.553286

Mahbib. (2019). Tata Cara Shalat Idul Fitri. Retrieved June 3, 2019, from nu.or.id website: http://www.nu.or.id/post/read/79070/tata-cara-shalat-idul-fitr

McNaughton, D., Morrison, M., \& Schill, C. (2016). 'My Country is like my Mother...': respect, care, interaction and closeness as principles for undertaking cultural heritage assessments. International Journal of Heritage Studies. https://doi.org/10.1080/13527258.2016.1165277

Meijering, J. V., Tobi, H., van den Brink, A., Morris, F., \& Bruns, D. (2015). Exploring research priorities in landscape architecture: An international Delphi study. Landscape and Urban Planning. https://doi.org/10.1016/j.landurbplan.2015.01.002

Mirawati, T. (2016). NILAI-NILAI ISLAM DALAM TRADISI GAREBEG MULUD DAN IMPLIKASINYA TERHADAP MASYARAKAT KERATON YOGYAKARTA (ISLAM NEGERI SUNAN KALIJAGA YOGYAKARTA). Retrieved from http://digilib.uinsuka.ac.id/20849/1/12510046_BAB-I_IV-atau-V_DAFTAR-PUSTAKA.pdf

Mulder, N. (2007). Mistisisme Jawa. Yogyakarta: LKis.

Muralidharan, S., \& La Ferle, C. (2018). Religious symbolism in the digital realm: A social advertising approach to motivate bystanders to aid victims of cyberbullying. International Journal of Consumer Studies. https://doi.org/10.1111/ijcs.12448

Nabulsi, M. R. (2012). The Social Aspect in Islam. Retrieved June 17, 2019, from muhammad-pbuh.com website: http://www.muhammad-pbuh.com/en/?p=372

Nasution, H. (1986). Akal dan Wahyu dalam Islam. Jakarta: UI Press.

Office of Economic Resilience Development Office of Community Planning and Development United States Department of Housing and Development. (n.d.). GREEN INFRASTRUCTURE AND THE SUSTAINABLE COMMUNITIES INITIATIVE. Retrieved from http://portal.hud.gov/hudportal/documents/huddoc?id=greeninfrastructsci.pdf

Pew Research Center. (2017). Penelitian : Islam Agama dengan Pertumbuhan Paling Cepat di Dunia. Retrieved from BBC News website: https://jogja.tribunnews.com/2017/06/02/penelitian-islam-agama-denganpertumbuhan-paling-cepat-di-dunia

Pucher, J., \& Buehler, R. (2010). Walking and cycling for healthy cities. Built Environment. https://doi.org/10.2148/benv.36.4.391

Putra, R. A. M. (2016). PELAKSANAAN UNDANG-UNDANG NOMOR 1 TAHUN 2011 TENTANG PERUMAHAN DAN KAWASAN PEMUKIMAN. Retrieved from https://media.neliti.com/media/publications/116400-ID-pelaksanaan-undang-undang-nomor-1tahun.pdf

Putra, R. B. (2012). PENGERTIAN DAN KONSEP NILAI DALAM ISLAM. Retrieved May 16, 2019, from academia.edu website: https://www.academia.edu/9238928/PENGERTIAN_DAN_KONSEP_NILAI_DALAM_ISLAM

Qian, C., Zhu, D., Zhou, Y., \& Chen, J. (2018). Measurements of pedestrian friendliness of residential area: A case study in Hexi District of Nanjing. Sustainability (Switzerland). https://doi.org/10.3390/su10061993 
Rahma, S. (2019). Pengertian Disiplin, macam macam disiplin dan manfaat disiplin. Retrieved June 7, 2019, from academia.edu website: https://www.academia.edu/8980066/Pengertian_Disiplin_macam_macam_disiplin_dan_manfaat_disi plin

Redaksi. (2019). Perda Larangan Bawa Senjata Tajam Diberlakukan di Jayawijaya.

SALZBRUNN, M. (2004). THE OCCUPATION OF PUBLIC SPACE THROUGH RELIGIOUS AND POLITICAL EVENTS: HOW SENEGALESE MIGRANTS BECAME A PART OF HARLEM, NEW YORK. Journal of Religion in Africa, 34(4). Retrieved from http://www.urbanlab.org/articles/Salzbrunn 2004 Senegalese New York.pdf

Sardar, Z. (1988). The Future of Muslim Civilization.

Suyono. (2012). Dunia Mistik Orang Jawa. LKis.

Tanuwidjaja, G., \& Chang, B. G. (2017). Green Infrastructure Concept for JABODETABEKJUR Metropolitan Area. IOP Conference Series: Earth and Environmental Science. https://doi.org/10.1088/1755-1315/79/1/012024

Travlou, P., \& Thompson, C. W. (2007). Open space: People space. In Open Space: People Space. https://doi.org/10.4324/9780203961827

Wallbank, N. J., \& James, P. (2010). Urban vegetation and the drivers for change: A case study of Runcorn, UK. COBRA 2010 - Construction, Building and Real Estate Research Conference of the Royal Institution of Chartered Surveyors.

Wardani, L. K., Soedarsono, R. M., Haryono, T., \& Suryo, D. (2013). City Heritage of Mataram Islamic Kingdom in Indonesia (Case Study of Yogyakarta Palace). The International Journal of Social Sciences.

Wibowo, E. (2012). Catur Gatra Tunggal, Konsep Tata Ruang Jawa.

Widarnaryani, C. K., \& Ikaputra, J. A. . (2003). Kajian Morfologi Dan Perubahan Fungsi Alun-Alun Utara Keraton Yogyakarta. Teknosains.

Widiyastuti, D. (2012). Memorable Square: Identities, Meanings and the Production of Urban Space in Yogyakarta, Indonesia. REAL CORP 2012.

Woolley, H. (2003). Urban open spaces. In Urban Open Spaces. https://doi.org/10.4324/9780203402146

Woolley, H., \& Rose, S. (2003). The Value of Public Space. How high quality parks and public spaces create economic, social and environmental value. CABE Space, Deparment for Culture, Media and Sport UK.

Yahya, I. (2018). Islam Rahmatan Lil'alamin. Retrieved July 3, 2019, from http://www.iainsurakarta.ac.id/?p=12750 